\title{
22. GEOCHEMISTRY, MINERALOGY, AND PETROLOGY OF BASALTS, LEG 25 , DEEP SEA DRILLING PROJECT
}

\author{
A. J. Erlank and D. L. Reid, Department of Geochemistry, University of Cape Town, Rondebosch, South Africa
}

\section{INTRODUCTION}

Basalt was recovered from five sites $(239,240,245,248$, and 249) drilled on Leg 25 of the Deep Sea Drilling Project. The recovered samples were originally glassy to holocrystalline basalt and diabase, now altered to varying degrees. Seven of the fresher samples were analyzed by X-ray fluorescence methods for major and trace elements, with $\mathrm{FeO}$ being determined by standard wet chemical methods. An additional sample from Site 248 was analyzed for trace elements. Major element analyses and C.I.P.W. norms are given in Tables 1 and 2 and trace element data are given in Table 3. Electron microprobe data for fresh glass from Site 240 are given in Table 4. Modal data are presented in Tables 5 and 6; those in Table 5 are derived from visual estimates only, while those in Table 6 for Site 248 are quantitative measurements obtained by standard point-counting techniques. Other mineralogical and chemical data are presented in subsequent tables (Tables 7 and 8 ).

Several recent studies have been concerned with the weathering of basalts recovered from the ocean floors and mid-ocean ridges, and it is clear that seawater alteration can produce substantial changes in the composition of abyssal basalt. The chemical data in this study are interpreted according to the conclusions of Hart et al. (in press). We have also followed the approach adopted by Melson and Thompson (1973) in calculating the C.I.P.W. norms with $\mathrm{Fe}_{2} \mathrm{O}_{3} / \mathrm{FeO}$ adjusted to 0.20 . The net effect for all samples is to reduce the amount of quartz in the norm; Samples DBI 6 (Site 240) and DBI 7 (Site 245) are both quartz normative if the norm is calculated according to the analyses in Table 1, but are olivine normative when calculated with $\mathrm{Fe}_{2} \mathrm{O}_{3} / \mathrm{FeO}=0.2$ (Table 2). The results show that all samples analyzed in this study are tholeiitic in character.

Further discussion of the basalts from each site is given below. Additional descriptions and data are also provided in the site reports in this volume.

\section{SITE 239}

Some 2.2 meters of dark gray basalt were recovered in Cores 20 and 21 at Site 239. The basalt has a fine-grained crystalline texture except in thin zones where glassy textures predominate. Reddish-brown zones, caused by iron oxidation during submarine weathering, follow irregular fractures that traverse the rock; some of these are filled with iron-stained carbonate and chert.

Microscopic examination reveals that both texture and modal composition (Table 5) vary quite considerably but unsystematically. Variolitic to intersertal textures predominate and plagioclase is intergrown with minute granules of augite, altered olivine, and opaque mineral, the crystalline network being set in a base of dark brown altered glass. Chlorite, goethite, calcite, and smectite (?) occur as secondary minerals. In places, intergranular and pilotaxitic textures also occur. Away from fractures, weathering and/or secondary alteration are not as marked, and these fractures could not be completely avoided when selecting the sample for chemical analyses. The fine-grained texture of the basalt precluded detailed modal and mineralogical analysis.

The major and trace element chemistries (Tables 1 and 3) show that the analyzed sample (DBI 5) is similar in composition to the typical low-K tholeiites recovered from spreading mid-ocean ridges, especially with regard to the low $\mathrm{Ba}$ and $\mathrm{Nb}$ contents. As noted above, the analyzed sample is somewhat altered, and it is highly probable that both $\mathrm{K}$ and $\mathrm{Rb}$, and especially the latter, have been added during seawater alteration, resulting in relatively low $\mathrm{K} / \mathrm{Rb}$ and relatively high $\mathrm{K} / \mathrm{Ba}$ and $\mathrm{Rb} / \mathrm{Sr}$ ratios (Hart et al., in press). An unusual feature is the presence of equivalent amounts of $\mathrm{Co}, \mathrm{Cr}$, and $\mathrm{Ni}$, as abyssal tholeiites (and the other samples in Table 3) generally contain much higher concentrations of $\mathrm{Cr}$ and $\mathrm{Ni}$. It is not possible to assess the significance of this feature at this stage, but it may be noted that the concentrations of $\mathrm{Co}, \mathrm{Cr}$, and $\mathrm{Ni}$ in the Site 239 basalt are similar to low-K tholeiites found in island arcs.

\section{SITE 240}

Core 7 contained 1.2 meters of very fine-grained dark gray basalt. The entire core is highly fractured, and calcite fills some fractures to a width of $1 \mathrm{~cm}$. Several glassy zones occur; the most apparent is at $33 \mathrm{~cm}$ where the basalt contains a baked chalk fragment. An electron microprobe analysis of this glass is given in Table 4 . The glass is locally extremely fresh and contains a few euhedral prismatic microphenocrysts of unzoned plagioclase which has a composition of $\mathrm{An}_{84}$ by microprobe analysis.

In the lower part of the core the basalt has a fine-grained pilotaxitic texture, suggestive of slight flowage before final consolidation. A few prismatic crystals of plagioclase and rounded pseudomorphs after olivine form microphenocrysts. The slightly fluidal arrangement of groundmass plagioclase and augite granules is set in a base of brown devitrified glass. Accessory amounts of magnetite, goethite, calcite, chlorite, and secondary clay minerals are present. A few microvesicles $(0.5-1.0 \mathrm{~mm}$ in diameter) are filled with calcite and chlorite.

The analyzed sample (DBI 6) is similar in composition to average mid-ocean ridge abyssal basalt, both with respect to major and trace elements. Because of the presence of fresh glass at the top of the basalt core, it is possible to estimate 
TABLE 1

Chemical Analyses of Basalt, DSDP Leg 25, and Average Composition of Mid-Ocean Ridge Abyssal Basalts (Wt \%)

\begin{tabular}{|c|c|c|c|c|c|c|c|c|}
\hline & $\begin{array}{c}239-20-1,114-122 \mathrm{~cm} \\
\text { (DBI 5) }\end{array}$ & $\begin{array}{l}240-7-1,80 \mathrm{~cm} \\
\text { (DBI 6) }\end{array}$ & $\begin{array}{c}245-19-1,75-82 \mathrm{~cm} \\
\text { (DBI 7) }\end{array}$ & $\begin{array}{c}248-15-1,73-84 \mathrm{~cm} \\
\text { (DBI 8) }\end{array}$ & $\begin{array}{c}248-17-2,49-54 \mathrm{~cm} \\
\text { (DBI 9) }\end{array}$ & $\begin{array}{l}249-33, \text { CC } \\
\text { (DBI 10) }\end{array}$ & $\begin{array}{c}249-33-3,58-67 \mathrm{~cm} \\
\text { (DBI 11) }\end{array}$ & $\begin{array}{l}\text { Average Abyssal } \\
\text { Basalt }^{\mathrm{a}}\end{array}$ \\
\hline $\mathrm{SiO}_{2}$ & 50.01 & 49.11 & 50.74 & 46.60 & 48.97 & 49.72 & 47.90 & 49.21 \\
\hline $\mathrm{TiO}_{2}$ & 1.37 & 0.826 & 1.27 & 2.67 & 2.25 & 0.748 & 0.750 & 1.39 \\
\hline $\mathrm{Al}_{2} \mathrm{O}_{3}$ & 15.20 & 15.87 & 14.41 & 18.28 & 16.04 & 15.76 & 15.81 & 15.81 \\
\hline $\mathrm{Fe}_{2} \mathrm{O}_{3}$ & 3.81 & 3.05 & 3.64 & 5.54 & 3.88 & 4.76 & 5.63 & 2.21 \\
\hline $\mathrm{FeO}$ & 5.57 & 5.35 & 6.78 & 3.61 & 6.75 & 4.02 & 3.45 & 7.19 \\
\hline $\mathrm{MnO}$ & 0.143 & 0.146 & 0.182 & 0.200 & 0.169 & 0.102 & 0.117 & 0.16 \\
\hline $\mathrm{MgO}$ & 6.70 & 8.00 & 7.21 & 3.24 & 5.14 & 7.04 & 6.58 & 8.53 \\
\hline $\mathrm{CaO}$ & 10.51 & 12.49 & 11.12 & 10.81 & 10.81 & 9.09 & 9.18 & 11.14 \\
\hline $\mathrm{Na}_{2} \mathrm{O}$ & 2.66 & 1.96 & 3.30 & 2.51 & 2.50 & 2.31 & 2.32 & 2.71 \\
\hline $\mathrm{K}_{2} \mathrm{O}$ & 0.368 & 0.345 & 0.041 & 1.19 & 0.270 & 0.439 & 0.372 & 0.26 \\
\hline $\mathrm{P}_{2} \mathrm{O}_{5}$ & 0.128 & 0.081 & 0.098 & 0.253 & 0.211 & 0.065 & 0.072 & 0.15 \\
\hline $\mathrm{H}_{2} \mathrm{O}$ & 1.81 & 1.64 & 1.18 & 1.10 & 1.73 & 4.02 & 4.37 & \\
\hline LOI $^{b}$ & 1.092 & 1.259 & 0.768 & 3.315 & 0.971 & 1.761 & 2.506 & \\
\hline S & 0.022 & 0.013 & 0.189 & 0.008 & 0.055 & 0.005 & 0.009 & \\
\hline Subtotal & 99.393 & 100.140 & 100.928 & 99.326 & 99.746 & 99.840 & 99.066 & 98.76 \\
\hline $\mathrm{O}=\mathrm{S}$ & 0.011 & 0.006 & 0.094 & 0.004 & 0.027 & 0.002 & 0.004 & \\
\hline Total & 99.382 & 100.134 & 100.834 & 99.322 & 99.719 & 99.838 & 99.062 & \\
\hline
\end{tabular}

${ }^{\mathrm{a}}$ From Melson and Thompson (1971).

${ }^{\mathrm{b}} \mathrm{LOI}=$ Loss at $1050^{\circ} \mathrm{C}$. 
TABLE 2

C.I.P.W. Weight Percent Norm

\begin{tabular}{lccccccc}
\hline & $\begin{array}{c}\text { DBI 5 } \\
\text { (Site 239) }\end{array}$ & $\begin{array}{c}\text { DBI 6 } \\
\text { (Site 240) }\end{array}$ & $\begin{array}{c}\text { DBI 7 } \\
\text { (Site 245) }\end{array}$ & $\begin{array}{c}\text { DBI 8 } \\
\text { (Site 248) }\end{array}$ & $\begin{array}{c}\text { DBI 9 } \\
\text { (Site 248) }\end{array}$ & $\begin{array}{c}\text { DBI 10 } \\
\text { (Site 249) }\end{array}$ & $\begin{array}{c}\text { DBI 11 } \\
\text { (Site 249) }\end{array}$ \\
\hline Q & 0.38 & - & - & 0.50 & 2.84 & 3.68 & 2.46 \\
Or & 2.30 & 2.10 & 0.25 & 7.39 & 1.64 & 2.77 & 2.36 \\
$\mathrm{Ab}$ & 22.84 & 16.67 & 28.51 & 21.32 & 21.24 & 19.54 & 19.71 \\
$\mathrm{An}$ & 29.46 & 34.70 & 24.84 & 37.20 & 32.91 & 33.87 & 34.72 \\
$\mathrm{Di}$ & 20.33 & 23.16 & 25.16 & 15.23 & 17.13 & 11.04 & 11.22 \\
$\mathrm{Hy}$ & 19.28 & 17.93 & 10.73 & 10.17 & 16.24 & 24.56 & 24.02 \\
$\mathrm{O1}$ & - & 1.51 & 5.87 & - & - & - & - \\
$\mathrm{II}$ & 2.65 & 1.60 & 2.44 & 5.24 & 4.34 & 1.49 & 1.51 \\
$\mathrm{Mt}$ & 2.35 & 2.04 & 2.51 & 2.25 & 2.60 & 2.16 & 2.25 \\
$\mathrm{Ap}$ & 0.32 & 0.20 & 0.24 & 0.63 & 0.51 & 0.16 & 0.18 \\
\hline
\end{tabular}

Note: Calculated water free and with $\mathrm{Fe}_{2} \mathrm{O}_{3} / \mathrm{FeO}=0.2$.

TABLE 3

Trace Element Concentrations in DSDP Leg 25 Basalts (ppm) and Average Composition of Mid-Ocean Ridge Abyssal Basalts

\begin{tabular}{|c|c|c|c|c|c|c|c|c|c|}
\hline & $\begin{array}{c}\text { DBI 5 } \\
\text { (Site 239) }\end{array}$ & $\begin{array}{c}\text { DBI } 6 \\
\text { (Site 240) }\end{array}$ & $\begin{array}{c}\text { DBI } 7 \\
\text { (Site 245) }\end{array}$ & $\begin{array}{c}\text { DBI 8 } \\
\text { (Site 248) }\end{array}$ & $\begin{array}{c}\text { DBI 12 }{ }^{\mathrm{a}} \\
\text { (Site 248) }\end{array}$ & $\begin{array}{c}\text { DBI 9 } \\
\text { (Site 248) }\end{array}$ & $\begin{array}{c}\text { DBI 10 } \\
\text { (Site 249) }\end{array}$ & $\begin{array}{c}\text { DBI 11 } \\
\text { (Site 249) }\end{array}$ & $A^{b}$ \\
\hline $\mathrm{K}$ & 3050 & 2860 & 340 & 9880 & 3490 & 2240 & 3640 & 3090 & 1160 \\
\hline $\mathrm{Ba}$ & 13 & 12 & 8 & 104 & 97 & 94 & 77 & 46 & 12 \\
\hline Co & 52 & 52 & 54 & 70 & 71 & 57 & 57 & 71 & 32 \\
\hline $\mathrm{Cr}$ & 53 & 403 & 161 & 165 & 140 & 156 & 249 & 228 & 296 \\
\hline $\mathrm{Cu}$ & 110 & 65 & 84 & 95 & 193 & 182 & 68 & 115 & 87 \\
\hline $\mathrm{Ga}$ & 16.5 & 13.7 & 16.6 & 23.0 & 22.5 & 21.5 & 14.9 & 15.4 & 18 \\
\hline $\mathrm{Nb}$ & 1.0 & 1.4 & 1.0 & 10.6 & 9.5 & 8.9 & 2.2 & 2.5 & 2.5 \\
\hline $\mathrm{Ni}$ & 48 & 149 & 70 & 89 & 97 & 95 & 167 & 178 & 123 \\
\hline $\mathrm{Rb}$ & 9.1 & 7.4 & $<0.5$ & 71 & 5.9 & 3.1 & 5.3 & 4.5 & 1.1 \\
\hline $\mathrm{Sr}$ & 122 & 76 & 79 & 252 & 254 & 219 & 103 & 107 & 123 \\
\hline V & 294 & 220 & 338 & 318 & 318 & 293 & 191 & 187 & 289 \\
\hline $\mathrm{Y}$ & 33 & 20 & 28 & 34 & 29 & 28 & 19 & 22 & 43 \\
\hline $\mathrm{Zn}$ & 98 & 71 & 89 & 127 & 110 & 107 & 79 & 82 & 122 \\
\hline $\mathrm{Zr}$ & 87 & 45 & 65 & 165 & 158 & 139 & 62 & 63 & 100 \\
\hline $\mathrm{K} / \mathrm{Rb}$ & 335 & 386 & $>680$ & 139 & 591 & 722 & 687 & 687 & 1054 \\
\hline $\mathrm{K} / \mathrm{Ba}$ & 235 & 238 & 43 & 95 & 36 & 24 & 47 & 67 & 97 \\
\hline $\mathrm{Rb} / \mathrm{Sr}$ & 0.075 & 0.097 & $<0.006$ & 0.282 & 0.023 & 0.014 & 0.051 & 0.043 & 0.009 \\
\hline $\mathrm{Zr} / \mathrm{Nb}$ & 87 & 32 & 65 & 16 & 17 & 16 & 28 & 25 & 40 \\
\hline
\end{tabular}

${ }^{\mathrm{a}}$ DBI $12=$ Site 248 , Core 17 , Section $1,132-140 \mathrm{~cm}$.

$\mathrm{b}_{\mathrm{A}}=$ Average mid-ocean ridge basalt, data from Engel et al. (1965); Hart (1971); Melson and Thompson (1971); and Hart et al. (in press).

the effects of seawater alteration by comparing the major element and normative data in Tables 1,2 , and 4. Taking into account the effects of analytical error and possible differences caused by igneous differentiation, the general agreement between the rock and glass analyses is satisfactory, except for potassium. The rock analyzed (DBI 6 , Table 1) contains almost six times as much potassium as found in the fresh glass (Table 4) and this most likely is related to the introduction of potassium during seawater alteration of the rock groundmass and the formation of secondary clay minerals. The relatively low $\mathrm{K} / \mathrm{Rb}$ and the high $\mathrm{K} / \mathrm{Ba}$ and $\mathrm{Rb} / \mathrm{Sr}$ ratios support this conclusion (Hart et al., in press).

The basalt from this site may be distinguished from the other samples analyzed and from average mid-ocean ridge basalt by its relatively high $\mathrm{Cr}$ and low $\mathrm{Sr}$ and $\mathrm{Zr}$ contents (Table 3); these elements are apparently not affected by seawater alteration processes (Hart et al., in press).
TABLE 4

Microprobe Analysis of Glass from Sample 240-7-1, $31-33 \mathrm{~cm}$

\begin{tabular}{lc|lc}
\hline & Weight Percent & & C.I.P.W. Norm \\
\hline $\mathrm{SiO}_{2}$ & 49.87 & $\mathrm{Or}$ & 0.35 \\
$\mathrm{TiO}_{2}$ & 0.79 & $\mathrm{Ab}$ & 17.09 \\
$\mathrm{Al}_{2} \mathrm{O}_{3}$ & 16.03 & $\mathrm{An}$ & 34.64 \\
$\mathrm{FeO}^{\mathrm{b}}$ & 8.46 & $\mathrm{Di}$ & 22.63 \\
$\mathrm{MnO}$ & 0.18 & $\mathrm{Hy}$ & 17.20 \\
$\mathrm{MgO}$ & 8.89 & Ol & 3.62 \\
$\mathrm{CaO}$ & 12.62 & Il & 1.48 \\
$\mathrm{Na}_{2} \mathrm{O}$ & 2.02 & Mt & 2.08 \\
$\mathrm{~K}_{2} \mathrm{O}$ & 0.06 & & \\
Total & 98.92 & & \\
\hline
\end{tabular}

${ }^{\mathrm{a}}$ Calculated with $\mathrm{Fe}_{2} \mathrm{O}_{3} / \mathrm{FeO}=0.2$.

${ }^{\mathrm{b}}$ Total $\mathrm{Fe}$ as FeO 


\begin{tabular}{|c|c|c|c|c|c|c|c|c|c|c|c|c|c|c|c|c|c|c|}
\hline & 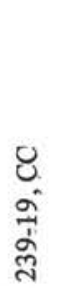 & 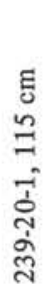 & 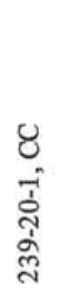 & 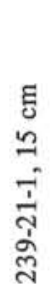 & 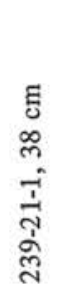 & 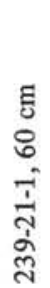 & 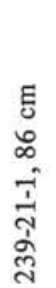 & 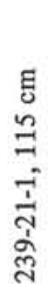 & 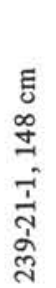 & $\begin{array}{l}\text { ㄱ } \\
\text { ì } \\
\text { j. } \\
\dot{d}\end{array}$ & 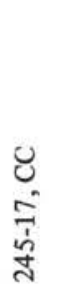 & \begin{tabular}{l} 
U \\
$\infty$ \\
\multirow{2}{n}{} \\
ปे
\end{tabular} & 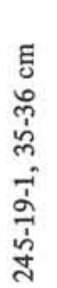 & 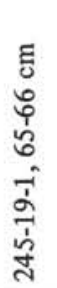 & 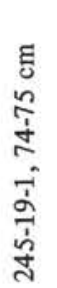 & 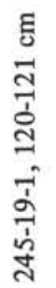 & 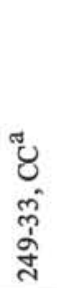 & $\begin{array}{l}\text { 己 } \\
\text { กิ } \\
\text { ๙่ } \\
\text { ते }\end{array}$ \\
\hline Plagioclase & 40 & 40 & 45 & 35 & 50 & 60 & 20 & 60 & 40 & 35 & 15 & 50 & 55 & 50 & 55 & 50 & 50 & 45 \\
\hline Augite & 2 & 3 & 15 & 10 & 3 & 30 & 5 & 30 & 15 & 25 & 10 & 35 & 35 & 30 & 30 & 35 & 23 & 44 \\
\hline Olivine $\mathrm{c}$ & - & $\mathrm{Tr}$ & - & - & 4 & 1 & - & 1 & - & $\mathrm{Tr}$ & 5 & - & - & - & - & - & - & - \\
\hline Opaques ${ }^{\mathrm{d}}$ & 8 & 2 & 3 & 3 & 1 & 3 & 3 & 3 & 3 & $\mathrm{Tr}$ & 3 & 5 & 5 & 10 & 5 & 5 & 8 & 6 \\
\hline Glass & 50 & 55 & 35 & 50 & 40 & 5 & 70 & 5 & 40 & 40 & 65 & 5 & 2 & 5 & 5 & 7 & - & - \\
\hline Carbonate & $\mathrm{Tr}$ & $\mathrm{Tr}$ & - & - & - & - & - & $\mathrm{Tr}$ & - & $\mathrm{Tr}$ & $\mathrm{Tr}$ & 2 & - & - & - & 1 & - & - \\
\hline Chlorite & $\mathrm{Tr}$ & $\operatorname{Tr}$ & 1 & 2 & 2 & 2 & 2 & $\operatorname{Tr}$ & 2 & $\mathrm{Tr}$ & 2 & 3 & 3 & 5 & 5 & 2 & - & - \\
\hline Chlorophaeite & - & $\mathrm{Tr}$ & 1 & - & - & - & - & - & - & - & $\operatorname{Tr}$ & - & $\operatorname{Tr}$ & - & - & $\operatorname{Tr}$ & 14 & 3 \\
\hline Amygdales $\mathrm{f}$ & - & - & - & - & - & - & - & - & - & - & - & - & - & - & - & - & 5 & 2 \\
\hline
\end{tabular}

\footnotetext{
${ }^{\text {a }}$ Fine-grained variety.

${ }^{b}$ Coarser grained (subophitic) variety.

${ }^{c}$ Olivine invariably pseudomorphed by chlorite, serpentine, iddingsite, carbonate, goethite.

${ }^{\mathrm{d}}$ Opaques include magnetite, ilmenite, pyrite.

${ }^{\mathrm{e}}$ Carbonates probably calcite, but dolomite and siderite may be present also.

${ }^{\mathrm{f}}$ Amygdales contain brown low $\mathrm{K}$ smectite, blue-green high $\mathrm{K}$ smectite, and calcite.
}

\section{SITE 245}

Core catchers of Cores 17 and 18 contain small fragments, each about $6 \mathrm{~cm}$ in length, as the only basalt recovery in these intervals; in Core 19 the full 1.5 meters of basalt were recovered. In Core 17 , the basalt is glassy to fine grained and greenish black in color, while Cores 18 and 19 contain medium-grained dark gray diabasic basalt (diabase). Unfortunately, neither the contact between the two textural types nor the contact with the overlying sediments was recovered. However, small xenoliths of the diabasic basalt apparently occur in the aphanitic basalt from Core 17 although the relationship is not clear. Veins that occur throughout the cores are filled with calcite and chlorite. Younger fractures, which in some places cut across the veins, are marked by reddish-brown iron stains.

The texture of Core 17 basalt is variolitic with slender prisms of plagioclase building a divergent plexus set in a base of dark brown devitrified glass and powdery magnetite. The size of the plagioclase prisms is seriate with the largest $(0.4 \mathrm{~mm})$ forming clusters intergrown with granular augite and altered olivine. Chlorite, calcite, and chlorophaeite occur as alteration products; vesicles up to 1 $\mathrm{mm}$ in diameter are filled with chlorite. Diabasic inclusions (?) have textures and modal compositions similar to the diabasic basalt in the underlying cores.

The diabasic basalt (DBI 7) in Cores 18 and 19 is medium grained and nonporphyritic and fairly fresh, except in narrow altered zones near fractures. Augite and plagioclase occur in subophitic intergrowths typical of diabase, the average length of the plagioclase prisms being $0.5 \mathrm{~mm}$. Between the augite-plagioclase intergrowths, voids are filled with granular magnetite and green chlorophaeite. Subhedral pseudomorphs of green chlorite after olivine up to $0.8 \mathrm{~mm}$ in size occur sporadically. The augite-plagioclase intergrowths are molded around the chlorite pseudomorphs, suggesting that olivine was probably the first mineral to crystallize. As shown in Table 5, the modal composition of the diabasic basalt is quite uniform.

The major and trace element data for the diabasic basalt from this site indicate that it may be classed as a mid-ocean ridge tholeiite. The analyzed sample is easily the freshest of those analyzed in this study; the low $\mathrm{K}$ and $\mathrm{Rb}$ concentrations are in accord with this conclusion. Noteworthy also is the relatively high S content, as S has been shown to be easily removed during seawater alteration (Hart et al., in press). McKee (this volume) dated the diabasic basalt by the $\mathrm{K} / \mathrm{Ar}$ method at $27 \pm 3$ m.y., thereby establishing its intrusive origin.

\section{SITE 248}

Some 3.6 meters of basalt were recovered in Cores 15, 16 , and 17 at Site 248 , and a small piece was also found in the core hole assembly from Core 18. Irregular veins filled with chlorite, calcite, and goethite occur throughout the entire core. Submarine weathering is slight and restricted to narrow reddish-brown zones adjacent to fractures in the uppermost part.

The distinctive feature of the basalt from Site 248 is the coarsely porphyritic texture. Large phenocrysts of glassygray plagioclase up to $12 \mathrm{~mm}$ in length are conspicuous throughout. The size and abundance of phenocrysts do not vary with depth, although the section recovered is not a 
TABLE 6

Modal Analyses of Basalt from Site 248

\begin{tabular}{|c|c|c|c|c|c|c|c|c|}
\hline & $15-1,1-3 \mathrm{~cm}$ & $15-1,8-9 \mathrm{~cm}$ & $15-1,25-26 \mathrm{~cm}$ & $15-1,75-76 \mathrm{~cm}$ & $16-1,110-112 \mathrm{~cm}$ & $16-1,132-134 \mathrm{~cm}$ & $17-1,132-140 \mathrm{~cm}$ & $17-2,49-54 \mathrm{~cm}$ \\
\hline \multicolumn{9}{|l|}{ Phenocrysts } \\
\hline Plagioclase & 22.6 & 24.8 & 32.3 & 24.7 & 23.7 & 22.6 & 28.9 & 26.3 \\
\hline Clinopyroxene & 1.2 & 2.7 & 6.4 & 3.7 & 1.2 & 0.4 & 2.3 & 2.7 \\
\hline Olivine & 4.1 & 5.0 & 3.8 & 3.8 & 0.5 & - & 0.4 & 3.9 \\
\hline Subtotal & 27.9 & 32.5 & 42.5 & 32.2 & 25.4 & 23.0 & 31.6 & 32.9 \\
\hline \multicolumn{9}{|l|}{ Groundmass } \\
\hline Plagioclase & & & & & 28.6 & 30.7 & 34.2 & 30.7 \\
\hline Clinopyroxene & & & & & 41.5 & 40.4 & 30.2 & 32.7 \\
\hline Chlorophaeite & & & & & 0.9 & 1.8 & 1.8 & 1.0 \\
\hline Carbonate & & & & & 0.9 & 1.2 & 0.4 & 0.6 \\
\hline Opaques & & & & & 3.0 & 2.9 & 1.8 & 2.1 \\
\hline Subtotal & 72.1 & 67.5 & 57.5 & 67.8 & 74.9 & 77.0 & 68.4 & 67.1 \\
\hline Total & 100.0 & 100.0 & 100.0 & 100.0 & 100.0 & 100.0 & 100.0 & 100.0 \\
\hline
\end{tabular}

${ }^{\mathrm{a}}$ For rocks in which the groundmass is aphanitic, only the total groundmass can be given.

TABLE 7

Microprobe Analyses of Plagioclases from Site 248 (Expressed as wt \% An)

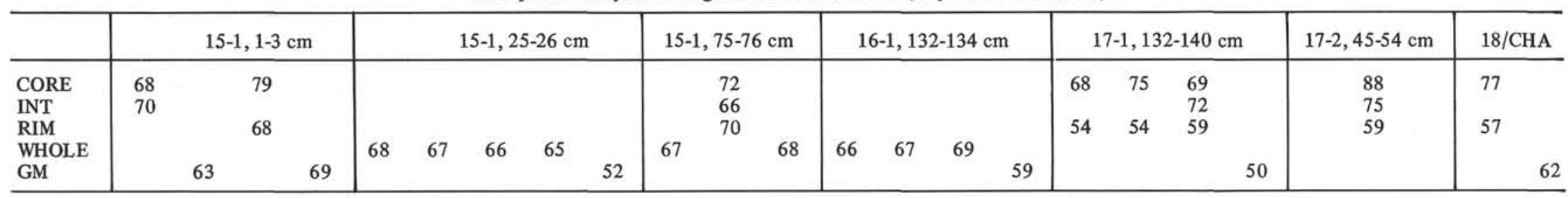

Note: Each vertical column of analyses represent those done on one individual phenocryst. INT $=$ intermediate zone, WHOLE $=$ single unzoned phenocryst, GM $=$ groundmass plagioclase, $\mathrm{CHA}=$ core hole assembly. 
TABLE 8

Trace Element Concentrations in Karroo Basalts from the Lebombo Structure (ppm)

\begin{tabular}{lcccccc}
\hline & LB 2 & LB 3 & KLL 11 & KLL 12 & KLL 13 & KL 2 \\
\hline $\mathrm{K}$ & 3300 & 6600 & 4000 & 7600 & 4000 & 4800 \\
$\mathrm{Ba}$ & 100 & 340 & 147 & 364 & 257 & 204 \\
$\mathrm{Co}$ & 50 & 47 & 59 & 42 & 43 & 48 \\
$\mathrm{Cr}$ & 78 & 81 & 43 & 172 & 82 & 52 \\
$\mathrm{Nb}$ & 5.5 & 12.4 & 3.0 & 5.6 & 5.3 & 12.7 \\
$\mathrm{Ni}$ & 86 & 53 & 59 & 74 & 72 & 45 \\
$\mathrm{Rb}$ & 9.7 & 21.2 & 4.7 & 17.7 & 7.0 & 10.2 \\
$\mathrm{Sr}$ & 376 & 480 & 152 & 482 & 513 & 203 \\
$\mathrm{~V}$ & 254 & 388 & 310 & 208 & 203 & 381 \\
$\mathrm{Y}$ & 34 & 44 & 27 & 22 & 21 & 39 \\
$\mathrm{Zr}$ & 150 & 203 & 102 & 113 & 117 & 192 \\
$\mathrm{~K} / \mathrm{Rb}$ & 340 & 311 & 851 & 429 & 571 & 471 \\
$\mathrm{~K} / \mathrm{Ba}$ & 33 & 19 & 27 & 21 & 16 & 24 \\
$\mathrm{Rb} / \mathrm{Sr}$ & 0.026 & 0.044 & 0.031 & 0.037 & 0.014 & 0.050 \\
$\mathrm{Zr} / \mathrm{Nb}$ & 27 & 16 & 34 & 20 & 22 & 15 \\
\hline
\end{tabular}

continuous one. However, the groundmass changes progressively from glassy at the top of the section (Core 15) to diabasic at the bottom (Core 18). Groundmass textures can be described as passing from hyaline, through hyalopilitic, intersertal and intergranular to subophitic (diabasic). Modal variation throughout the section is not marked and is summarized in Table 6.

Accompanying plagioclase as phenocryst minerals are augite and olivine. No fresh olivine occurs, however, its place is taken by a host of secondary minerals including carbonate, goethite, magnetite, and chlorite. The pseudomorphs are subhedral and range in size from $0.2 \mathrm{~mm}$ up to $0.9 \mathrm{~mm}$. In places, they are poikilitically enclosed in plagioclase and augite; their presence as inclusions does, however, point to a slightly earlier commencement of crystallization for olivine. Augite forms fresh subhedral crystals, often clustered together in synneusitic clots up to $2 \mathrm{~mm}$ across. The crystals contain many cracks, but are generally free of inclusions, zoning, and exsolution.

Plagioclase phenocrysts are invariably euhedral to subhedral, forming stout prisms of variable size. Twinning is ubiquitous, with the Albite law by far the most prevalent, followed by combined Carlsbad-Albite and Albite-Pericline. Zoning is very common but is not simple. Microprobe studies of the zoning in the plagioclase phenocrysts throughout the section fail to show any systematic compositional variation (Table 7). Fine-scale oscillatory zoning is present in many phenocrysts, indicating fluctuations in the pressure (P) and temperature (T) conditions that prevailed during intratelluric crystallization. Compositionally, variation within the oscillatory zones is never more than 10 percent $\mathrm{An}$, so the $\mathrm{P}, \mathrm{T}$ fluctuations were not very great. However, in some cases, the fluctuations appear to have been sufficiently large to remove plagioclase from the liquidus, because the interiors of some large crystals show oscillatory zoning that is truncated by a later growth phase, which also exhibits oscillatory zoning. Up to three periods of partial resorption and continued growth have been observed in some complex phenocrysts. Small bleb-like inclusions of glass commonly follow the line of truncation. The euhedral form of the majority of the plagioclase crystals and the alignment of the zoning with the crystal faces argues against their being xenocrysts, although it is possible that the cores of many large crystals may be xenocrystic in origin. Unfortunately, it was not possible to carry out a similar study on the coexisting pyroxene phenocrysts, but it is likely that this will provide further information on the pre-eruption history of the basalt magma that gave rise to the Site 248 rocks.

The rocks analyzed from Site 248 (DBI 8 and DBI 9) are tholeiites, but their compositions are distinct from all other samples analyzed in this study and from the average mid-ocean ridge abyssal tholeiite (Tables 1 and 3). However, caution should be exercised when interpreting these differences and the relationship of the Site 248 basalts to each other in view of the alteration which has affected these samples. Sample DBI 8 has unusually high $\mathrm{K}$ and $\mathrm{Rb}$ contents, and the extremely low $\mathrm{K} / \mathrm{Rb}$ ratio is, to our knowledge, the lowest $\mathrm{K} / \mathrm{Rb}$ ratio yet reported for an abyssal basalt. Qualitative electron microprobe observations show high concentrations of $\mathrm{K}$ associated with altered areas and secondary minerals in the groundmass of this sample. Taken in conjunction with the work of Hart et al. (in press), it seems clear that substantial amounts of $\mathrm{K}$ and $\mathrm{Rb}$ have been added to this sample, even though it did not appear that altered when selected for analysis. The much lower concentrations of $\mathrm{K}$ and $\mathrm{Rb}$ in Sample DBI 9 would thus appear to be more representative of the original concentrations in Site 248 basalt; on this basis, some addition of $\mathrm{K}$ and $\mathrm{Rb}$ has also occurred in Sample DBI 12 (Table 3) during seawater alteration.

Several other elements (e.g., $\mathrm{SiO}_{2}, \mathrm{Al}_{2} \mathrm{O}_{3}, \mathrm{MgO}$ ) show differences in composition between DBI 8 and DBI 9 and also from the other analyses in Table 1, but in view of the comments expressed above, no further interpretation will be made at this stage. Discussion will be limited to those elements which, according to Hart et al. (in press), are not susceptible, or only slightly so, to change by seawater alteration processes.

The concentrations of the ferromagnesian elements $\mathrm{Co}$, $\mathrm{Cr}, \mathrm{Ni}$, and $\mathrm{V}$ in the Site 248 basalts are within the ranges reported for other samples in Table 3; in contrast, the Site 248 samples have appreciably higher concentrations of $\mathrm{Ti}$, $\mathrm{Ba}, \mathrm{Sr}, \mathrm{Ga}, \mathrm{Zr}$, and $\mathrm{Nb}$ (some of these are commonly referred to as incompatible elements). The concentration levels of these elements fall within the range we have 
observed for Karroo lavas from the Lebombo region (Table 8 ) and for tholeiites from Hawaii and Iceland. Reference to other recent studies on abyssal basalts (e.g., Hart 1971) indicates that the high concentrations of incompatible elements in the Site 248 basalts are best interpreted as implying that these lavas are derived from source areas which are less depleted in these elements than the source areas of the other samples listed in Table 3. Interelement ratios are useful in this respect. Thus, the $\mathrm{Zr} / \mathrm{Nb}$ ratios of the Site 248 samples (neither of these elements is affected by seawater alteration processes) are lower than those shown for the other samples in Table 3, and this may be taken as evidence for a more primitive source area for these rocks (Kable and Erlank, in press). $\mathrm{Sr} 87 / \mathrm{Sr} 86$ measurements are required to substantiate this interpretation.

\section{SITE 249}

Core 33 from Site 249 contained 3 meters of basalt. The uppermost portion is glassy, highly vesicular, and weathered. Vesicles filled with calcite and green clay minerals are numerous and calcite vein-filling occurs at several places; the size and abundance of the vesicles decreases with depth. The sample from 33, CC shows an abrupt change in texture and vesicularity (Figure 1a), with the lower portion more massive and crystalline and containing clots of pyroxene $0.8 \mathrm{~mm}$ in diameter. The texture in thin section is hyalopilitic to intersertal, depending on the degree of crystallinity. Slender laths of plagioclase, $0.1-0.2 \mathrm{~mm}$ in length, are loosely intergrown with granular clinopyroxene. The interstitial voids are filled with green chlorophaeite and other alteration products, dark brown altered glass, granular magnetite, and calcite. A few anhedral microphenocrysts of plagioclase, their centers choked with tiny inclusions of the goundmass, also occur.

Detailed X-ray diffraction studies of Site 249 basalt by I. Zemmels revealed the presence of substantial amounts of montmorillonite-like clay minerals and the zeolite clinoptilolite, both in the bulk samples and in finer fractions, attesting to the altered nature of the samples. We separated an amygdale containing a blue-green clay mineral from Sample 33, CC which on X-ray diffraction yielded the following low angle peaks: $16.43 \AA$ (broad), $12.63 \AA$ (sharp), $11.26 \AA$ (sharp). The peak at $12.63 \AA$ was noted by Wright et al. (1972) in a study of basalt from Site 137 of DSDP Leg 14; they identified the secondary clay mineral as a smectite. In thin section, the vesicles in Sample 33, CC are filled largely with a blue-green mineral forming groups of spherules about $0.5 \mathrm{~mm}$ in diameter; minor amounts of a similar looking brown mineral also occur, both being set in a base of calcite. At higher magnification, the spherules can be seen to be made up of aggregates of radiating needles. These features are illustrated in Figure 1. Electron microprobe observations on the large vesicle in Figure 1 show that the blue-green and brown minerals are similar in composition, except with respect to $\mathrm{K}$ and $\mathrm{Mg}$. The former has approximately 8 percent $\mathrm{K}$ and 4 percent $\mathrm{Mg}$, and the latter approximately 0.3 percent $\mathrm{K}$ and 10 percent $\mathrm{Mg}$.
Quantitative measurements were unfortunately not possible because of the poor polish on the section and the fine-grained nature of the minerals concerned. However, the available evidence indicates that the blue-green and brown minerals are probably high-K and low-K smectites, formed by replacement during seawater alteration processes. They appear to be related to the potassian smectites recently described by Melson and Thompson (1973) in abyssal basalts from near St. Paul's Rocks, and their presence has obvious implications for K-Ar dating of such samples.

The two samples analyzed (DBI 10 and DBI 11) are also similar in composition to average mid-ocean ridge abyssal tholeiites. As shown by petrographic examination, they are moderately altered and this is manifested, interalia, by their relatively high $\mathrm{H}_{2} \mathrm{O}^{-}, \mathrm{K}$, and $\mathrm{Rb}$ contents, high $\mathrm{Fe}_{2} \mathrm{O}_{3} / \mathrm{FeO}$ ratios, and low $\mathrm{S}$ contents. These observations are in accord with the development of secondary clay minerals, as discussed above. The most notable difference between the Site 249 basalts and the average abyssal basalt in Table 3 is the relatively higher concentration of $\mathrm{Ba}$ in the former. However, the Site 249 basalt samples themselves have appreciably differing Ba contents. This is difficult to explain in view of the very similar $\mathrm{Sr}, \mathrm{Zr}$, and $\mathrm{Nb}$ concentrations in the two samples. Possibly $\mathrm{Ba}$ has also been severely affected by seawater alteration in this case. Sample DBI 10 could then be considered to be the more altered, resulting in the higher $\mathrm{Ba}$ content and lower $\mathrm{K} / \mathrm{Ba}$ ratio observed.

One of the objectives of Leg 25 was to identify the basement so as to provide evidence regarding the nature of the Mozambique Ridge which has variously been considered to be of either continental or oceanic origin. In order to further evaluate this problem, analyses have been made of Karroo (Stormberg) lavas from the Lebombo monocline, because of the proximity and possible relationship of this structure to the Mozambique Ridge. Trace element data are presented in Table 8; the samples are from Swaziland and northern Natal, i.e., the southern end of the Lebombo structure, and they have been analyzed by the same techniques used for the Leg 25 basalts; hence, the respective sets of data are comparable. It is apparent that the Site 249 samples (DBI 10 and DBI 11) have higher concentrations of $\mathrm{Cr}$ and $\mathrm{Ni}$ and lower concentrations of $\mathrm{Ba}, \mathrm{Sr}$, and $\mathrm{Zr}$ (and also $\mathrm{K}$ and $\mathrm{Rb}$ if allowances are made for alteration) than the Karroo samples. The available evidence indicates that the Site 249 basalts have closer compositional affinities with mid-ocean ridge basalts than with the Karroo lavas. The implication that the Mozambique Ridge is of oceanic origin must, however, be considered in the light of previous discussion where it was shown that the Site 248 basalts have compositional similarities with the continental Karroo lavas. As the Site 248 lavas are considered to be of oceanic origin, it is clear that a better understanding of trace element variations in basaltic rocks must be at hand before such variations can be unambiguously used to define whether specific volcanic rocks are representative of an oceanic or continental geo-environment. 


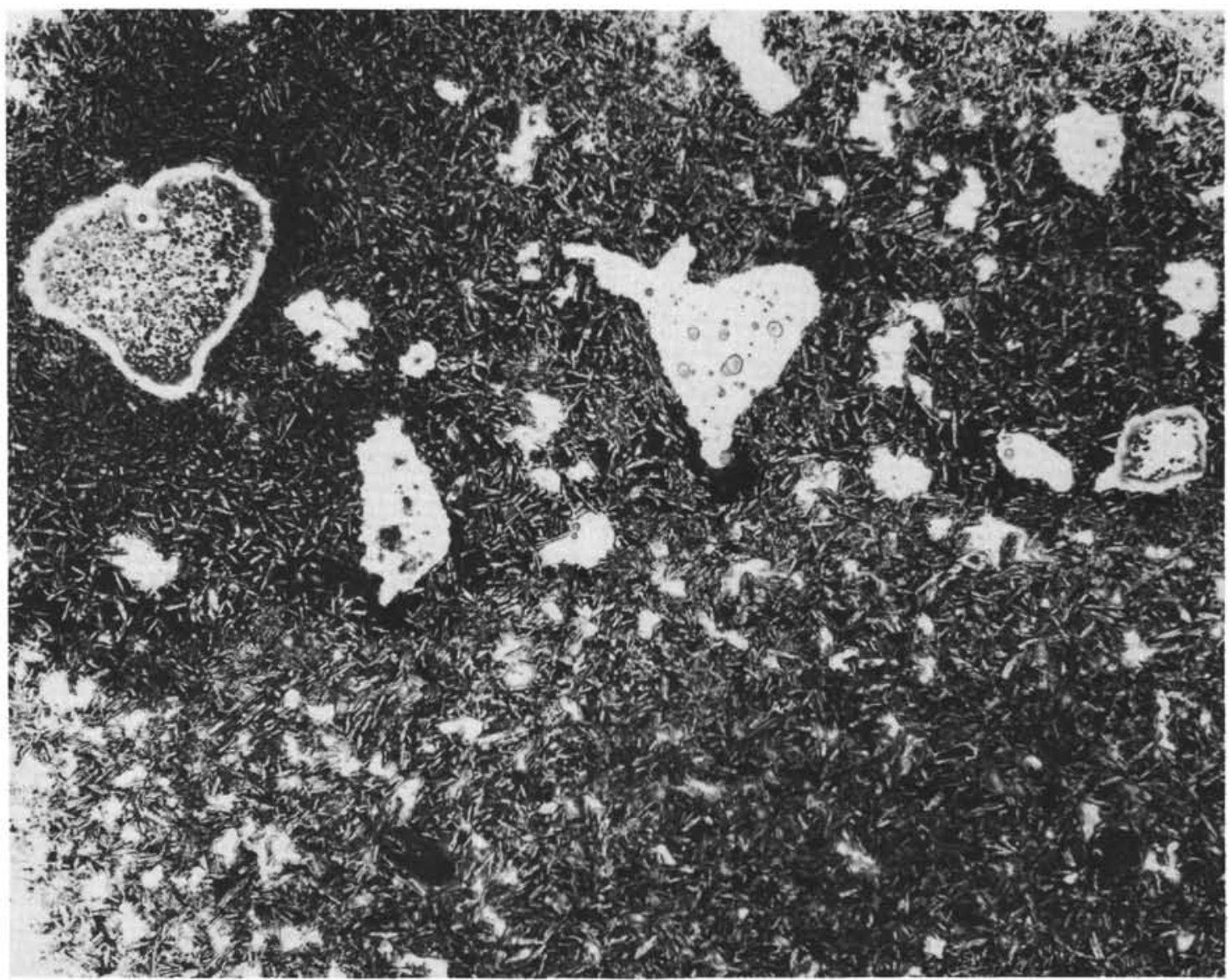

(a)

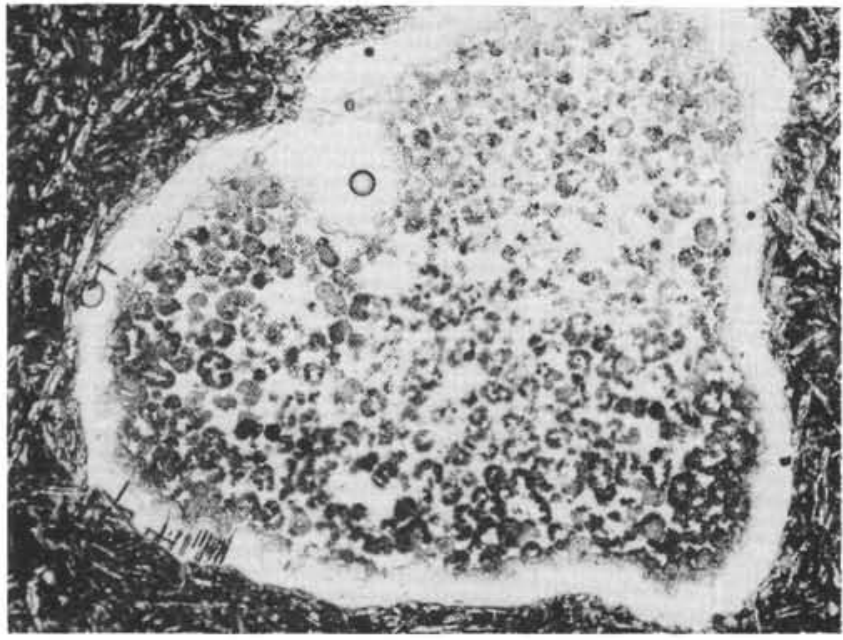

(b)

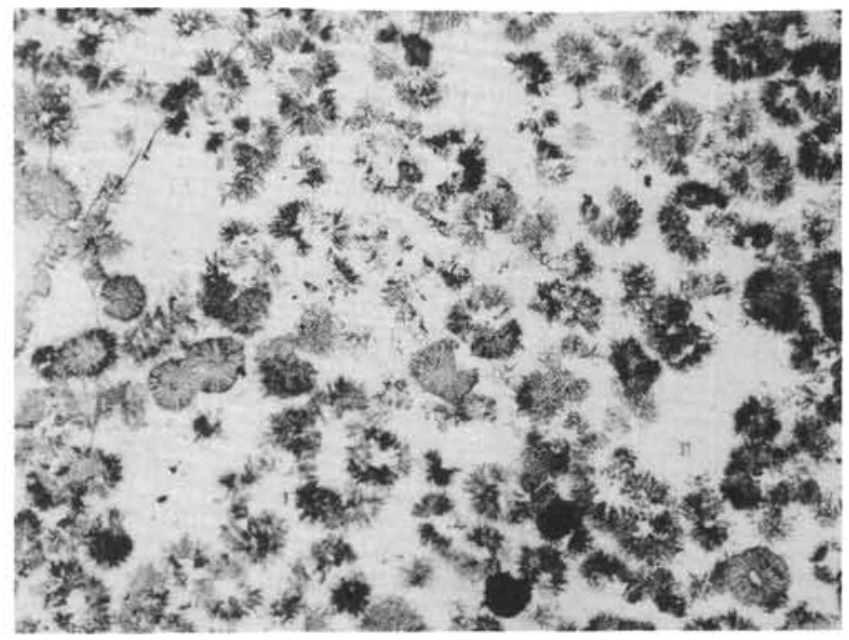

(C)

Figure 1. (a) Photomicrograph of amygdaloidal basalt from Site 249 (33, CC). Note the sharp undulating contact between two textural types. The upper type contains more glass (black areas) and more amygdales, most of which has been ground out of the slide. Width of the photograph is equivalent to $17 \mathrm{~mm}$. (b) Closer view of the amygdale at top left in 1 (a). It is filled with spherules of smectite (dark gray) set in a base of white calcite. Width of amygdale is $3 \mathrm{~mm}$. (c) Detail of the structure within the smectite spherules in 1 (b). Two varieties of smectite occur: (1) a blue-green, high $K$ variety and (2) a light-brown, low $K$ variety. Unfortunately, both types appear gray in the photograph except where the light-brown variety has been blackened by electron bombardment during microprobe analysis, e.g., the two dark spots at the bottom of the photograph, slight right of center. Width of photo is equivalent to $1 \mathrm{~mm}$. 


\section{REFERENCES}

Engel, A. E. J., Engel, C. E., and Havens, R. G., 1965. Chemical characteristics of oceanic basalts and the upper mantle: Geol. Soc. Am. Bull., v. 76, p. 719.

Hart, S. R., 1971. K, Rb, Cs, Sr and $\mathrm{Ba}$ contents and $\mathrm{Sr}$ isotope ratios of ocean floor basalts: Phil. Trans. Roy. Soc. London, Series A, v. 268, p. 573.

Hart, S. R., Erlank, A. J., and Kable, E. J. D., in press. Sea floor basalt alteration: some chemical and $\mathrm{Sr}$ isotopic effects: Con. Min. Petrol.

Kable, E. J. D. and Erlank, A. J., in press. Geochemical features of lavas from the Mid Atlantic Ridge at $45^{\circ} \mathrm{N}$, with special reference to the $\mathrm{Zr} / \mathrm{Nb}$ ratio: Earth Planet. Sci. Lett.

Melson, W. G. and Thompson, G., 1971. Petrology of a transform fault zone and adjacent ridge sediments: Phil Trans. Roy. Soc. London, Series A, v. 268, p. 423.

1973. Glassy abyssal basalt, Atlantic sea floor near St. Paul's Rocks: Petrography and composition of secondary clay minerals: Geol. Soc. Am. Bull., v. 84, p. 703.

Wright, T. L., Benson, W. E., Melson, W. G., and Hart, S. R., 1972. Petrology of basaltic rocks collected from Leg 14. In Hayes, D. E., Pimm, A. C., et al., Initial Reports of the Deep Sea Drilling Project, Volume XIV: Washington (U. S. Government Printing Office), p. 767. 